\title{
Presentation of the monograph. Culture and Populism in the Global South
}

Coordinated by

Pablo Valdivia

UNIVERSITY OF GRONINGEN

Manuel de la Fuente

UNIVERSITAT DE VALÈNCIA

\section{INTRODUCTION}

The debate on populism has been in the limelight over the last few years. Factors such as the 2007 Financial Crisis, the emergence of populist parties in Europe, and ideological polarisation (seen in Trump's arrival at The White House and in Brexit) beg questions about the geo-political balance struck in The West after the fall of the Soviet bloc in the 1990s. The successive crises unleashed after the fall of Lehman Brothers and the swift rise in various far-right parties in Europe reveal the fragility of The Capitalist Order, which is far from solving structural social problems. Hence the popularity of the word populism in media debates trying to explain the emergence of new political players opposing hegemonic discourses on the contemporary world.

There is also intense debate on populism in academe. Studies on populism have also taken centre stage in The Humanities and Social Sciences over recent years as a result of political, social, and cultural construction processes in various contexts. These processes have shown that the notion of populism is a very pliable one, and is used by governments, opposing ideologies, and diverse political regimes to suit their purposes. Experience of Latin American populism provides interesting comparisons with the brands of populism found in Europe and in The United States, which are articulating the drivers of inequality in what has become known as 'The Global South'. 
This monographic issue reflects theoretically on the current state of affairs, taking the most recent critical approaches to the subject as its point of departure. ${ }^{\mathbf{1}}$ This special issue seeks to close the present research gap by: (1) examining the mobilisation of a set of multi-disciplinary, trans-national theoretical perspectives to fully grasp the complex relationships between culture, inequality, and the public sphere in The Global South; (2) taking a critical approach to the cultural-political challenges posed by populist discourses and attitudes; (3) critically delving into the political, historical, cultural, and linguistic models shaping individual and collective imaginaries in The Global South; (4) undertaking critical reflection on the multi-disciplinary theoretical tools helping us to come up with analyses and models in keeping with the new social, cultural and political phenomena making up what we term 'populist cultural narratives'.

The reflections contained in the papers are the fruits of: (a) rigorous analysis and pooling of ideas among scholars drawn from several countries; (b) three Winter Schools on "Culture and Populism", forming part of the official programme of Winter Schools run by Groningen University. The first edition of this Winter School was held at Universidad de Granada in 2017), and in Valencia with the collaboration of Universitat de València (UV) (in the two subsequent editions, both held at Colegio Mayor Rector Peset in the third week of February in 2018 and 2019). There, academic and cultural centres in The Netherlands, The United States, Spain, France, Portugal, Peru, and Chile raised several key questions for framing the debate on the challenges currently posed by populism.

This monographic issue includes some of the most important contributions arising from these gatherings, offering a multi-disciplinary perspective on the subject. Stefan Couperus and Pier Domenico Tortola open the debate with the (ab)use made of history in populist discourse. An analysis is then made of some of the core discursive elements, such as the dichotomy between "us and them" (in Judith Jansma's paper), the logic behind negating the hegemonic order (explored in Luis Martín-Estudillo's paper), or the narrative elements of a nostalgia for a utopian past (Dora Vrhoci's contribution), concluding with the Latin American case, which is analysed by Carlos del Valle. The monographic issue thus offers a broad analysis contributing to future studies on populism - a phenomenon that is increasingly present in the discourses and policies adopted by diverse political players on the world stage.

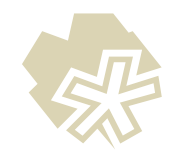

1 Among others, see Nestor García Canclini, La globalización imaginada, 2009; Manuel Castells (ed.) Aftermath: The Cultures of the Economic Crisis, 2012; Boaventura de Sousa Santos (ed.), Epistemologías del sur, 2014; Ruth Wodak, The Politics of Fear: What Right-Wing Populist Discourses Mean, 2015; Manfred Nowak. Human Rights or Global Capitalism: The Limits of Privatization, 2016: Lars Rensmann The Politics of Unreason: The Frankfurt School and the Origins of Modern Antisemitism, 2017; Manuel de la Fuente and Pablo Valdivia (eds.) Culture, Crisis, and Renewal in Spain. Special Issue in Romance Quarterly, 2017; Pablo Valdivia, Spanish Literature, Crisis and Spectrality: Notes on a Haunted Canon. 2018, among others. 